\title{
EENE UITGAVE VAN BESCHEIDEN BETREKKELIJK DE FILIPPIJNEN.
}

Het buitenlandsch medelid van 't Koninklijk Instituut, W. E. Retana, heeft onlangs een begin van uitvoering gegeven aan een veelomvattend plan, door 't eerste Deel te laten verschijnen van een werk getiteld Archivo del Bibliófilo Filipino '. De verzamelaar van 't Archief betoogt daarin vooral op te nemen zeldzaam geworden documenten, en voorts ook een plaats in te ruimen aan belangrijke geschriften van tijdgenooten, die om de een of andere reden de vruchten van hun studiën niet ter perse hebben kunnen leggen. Het behoeft geen betoog dat indien zekere belangrijke bronnen voor de geschiedenis, taal-, land- en volkenkunde der Filippijnen zelfs in Spanje moeielijk te verkrijgen zijn, dit in andere landen nog in veel hoogere mate het geval zal wezen, en daarom hopen wij van harte dat het streven van den Heer Retana allereerst bij zijn landgenooten, maar ook ten onzent en elders die waardeering zal vinden welke het ten volle verdient. Om het groote historische feit, dat zulk een groot deel van Azië onder de heerschappij van ettelijke Europeesche volken gekomen is, in zijn oorzaken en gevolgen goed te begrijpen en juist te beoordeelen, is het wenschelijk de geschiedenis aller Europeesche nederzettingen te bestudeeren. Wanneer men nagaat welke rol de Europeanen gedurende de laatste vier eeuwen in Azië gespeeld hebben, dan zal men, geloof ik, in de geschiedenis hunner heerschappij, ondanks enkele nationale verschillen en ondanks tijdelijke vijandschap, eene zekere gelijkvormigheid ontwaren, welke het natuurlijk gevolg is van de grondslagen waarop de Europeesche beschaving berust. Er zijn tijden geweest dat Portugeezen, Spanjaarden, Hollanders, Engelschen elkander heftig beoorloogden en zich meenden te verrijken door hun tegenstanders te benadeelen. De gevoelens waardoor

1 Volledige titel: Archivo del Bibliófilo filipino. Recopilación de documentos históricos, científicoss, literarios y políticos y estudios bibliográficos por W. E. Retana. Tomo primero. - Madrid 1895. - 465 pp. - Pr. 4 Pesetas.

6e Volgr. II. 
vijandschap gekweekt werd zijn nog niet geheel en al uitgestorven; opwellingen van hat en nijd komen ook nu nog voor, maar over 't algemeen begrijpt men beter dan in 't verleden dat het welbegrepen eigenbelang der Europeanen in 't Oosten niet vereenigbaar is met de vernedering of vernietiging van een eerlijken mededinger. Wat ous, Nederlanders, in 't bijzonder aangaat, wij zijn blijde zulke bevriende naburen in den Indischen Archipel te hebben als de Spanjaarden zijn, wier literarische werkzaamheid op de Filippijnen onze bewondering wekt.

Het eerste stuk in het Archief is de herdruk van een document gedrukt te Sevilla in 1826. Het bevat een "Waarachtig verhaal van den staat der oorlogen in de Filippijnen en de Rijken van Japan, tegen de Hollanders. En de roemruchtige daden van Don Fernando de Silva, benevens de groote overwinning die de Spanjaarden behaalden, waarbij 400 Hollanders afgemaakt werden." De titel beantwoordt niet geheel aan den inhoud, want er is geen sprake in 't stuk van een oorlog tegen de Hollanders in de Filippijnsche wateren, maar van de overwinning, door de Portugeezen op de Hollanders behaald bij Macao. De passage die hierop betrekking heeft, luidt in 't Archief, blz. 6, in vertaling aldus: "Om dezen tijd heeft Don Fernando de Silva, die als LuitenantGeneraal van den tegenwoordigen Gouverneur uitkwam, zich steeds zulk een bekwaam legeroverste betoond dat men hem aan 't hoofd van 200 Spanjaarden uitzond om der stad Macao, die de Portugeezen in bezit hebben, te hulp te komen. Er waren bij die gelegẹnheid Hollanders met een vloot voor Macao verschenen. Zij landden met 400 man en omsingelden de stad, doch die van Macao deden een uitval in goede orde en met beleid, en vielen de Hollanders zoo moedig aan, dat alle 400 op 't slagveld afgemaakt werden. En toen de Portugeezen zagen dat de Hollanders zich op nieuw gereed maakten om deze nederlaag te wreken, verzochten zij hulp bij den Gouverneur van Manila, en het was bij deze zoo eervolle gelegenheid dat Don Fernando de Silva met zijne 200 uitgezochte Spanjaarden zoo wel door de Portugeezen ontvangen werd, en om zijne aangename manieren zeer geacht. Zij vertrouwden hem 't bevel toe over een schip dat voor gemeenschappelijke rekening met koopwaren bevracht was, en hiermede kwam hij landen in 't koninkrijk Siam, en zeilde de rivier op." Iets verder vernemen wij dat "de Japanners - die daar in grooten getale zijn - uit hebzucht het schip wilden aanvallen, doch Don 
Fernando de Silva begreep hun toeleg, en weerstond hun met zijn infanterie. De Hollanders, die daar ' eene factorij hebben, poogden de omwoners over te halen om hen te helpen en het schip aan te tasten." Doch het schip had een bemanning van 300 koppen en meer dan genoeg oorlogstuig om zich te verdedigen, zoodat men van de beraamde onderneming afzag.

Men ziet, hier is geen sprake van eene overwinning der Spanjaarden; wel van eene nederlaag der Hollanders. De gebeurtenis, in 't Verhaal bedoeld, kan geen andere zijn dan die welke in een vorigen jaargang dezer Bijdragen ${ }^{2}$ door Tiele in de volgende bewoordingen beschreven is.

"Reijersz bevond dat Macao beter versterkt en bezet was dan men verwacht had, maar achtte 't toch doenlijk zich van die Portugeesche eilandstad meester te maken. Na haar een paar dagen beschoten te hebben, deed men den 24. Juni [1622] eene landing met 600 man in de baai van Castilhas aan de oostzijde van 't eiland. Eene batterij, door de Portugeezen bij de landingsplaats opgeworpen, werd veroverd en nu trok men op de stad aan. Op een heuvel aan dien kant lag het fort S. Paolo of do Monte, waaruit de Portugeezen nu de aanvallers beschoten. Ook werden de laatsten door het springen van eenige vaten kruid gedwongen op nieuwen aanvoer uit de schepen te wachten. De Portugeezen, door Japansche overloopers hiervan onderricht, deden hierop eenen uitval en sloegen de aanvallers op de vlucht. De achterhoede, die aan 't strand bij de booten wachtte, de anderen ziende aankomen, zocht zich het eerst te redden, zoodat nog vele manschappen bij het inschepen gedood werden. De Hollanders telden 130 dooden en evenveel gekwetsten. Het verlies der Portugeezen was onbeteekenend. Reijersz had bij de landing een schot in de buik gekregen en daardoor de leiding aan anderen moeten overlaten."

Het leidt weinig twijfel dat het Verhaal eerst geruimen tijd na de beschreven gebeurtenissen opgesteld is, en afkomstig, niet van een ooggetuige, gelijk uit den geheelen toon van 't stuk blijkt, maar van iemand die de toedracht der zaken alleen van hooren zeggen en vrij oppervlakkig wist. Vandaar dan ook dat alle datums in 't Verhaal ontbreken. In 't laatste gedeelte worden eenige bijzonderheden vermeld van de Christenvervolgingen in Japan. Vermoe-

1 Zeker wel te Bangkok.

2 Jaargang 1886-87, blz. 293, vg., waar behalve de Hollandsche, ook de Portugeesche en Italiaansche bronnen gebruikt en vermeld zijn. 
delijk slaat het bericht op de hevige vervolgingen in de laatste jaren van Iyeyasu, en de eerste van diens zoon Hidétada, omstreeks 1622 '.

Van de overige negen stukken die in 't Archief opgenomen zijn en, naar het mij voorkomt, grooter waarde hebben dan 't document van 1826, verdienen twee geschriften meer in 't bijzonder onze aandacht; namelijk een thans voor 't eerst gedrukt handschrift van den Pater Francisco Bencuchillo over "De Dichtkunst der Tagalen", en een opzettelijk voor 't Archief geschreven opstel van Pater José Castaño, getiteld: "Kort bericht omtrent de afkomst, den godsdienst, het geloof en bijgeloof der Bikols in den ouden tijd." Het is, ondanks den bescheiden titel het uitvoerigste wat over het behandelde onderwerp bestaat; ten minste voor zoover mij bekend is.

Het deel eindigt met een "Epitome eener algemeene Filippijnsche bibliographie", eerste gedeelte, door den Heer Retana zelven bewerkt.

\section{H. KRRX.}

1 Vgl. William E. Griffis, The Religions of Japan, blz. 343. 